\title{
Influence of Viral Marketing Dimensions on Customer Satisfaction in Fast Food Restaurants in Jordan
}

\author{
Ayed Al Muala ${ }^{1}$ \\ ${ }^{1}$ Faculty of Administrative and Financial Sciences, Zarqa University, Zarqa, Jordan \\ Correspondence: Ayed Al Muala, Faculty of Administrative and Financial Sciences, Zarqa University, Zarqa, \\ Jordan.
}

Received: January 28, 2018

Accepted: February 19, 2018 Online Published: February 26, 2018

doi:10.5539/jms.v8n1p149

URL: https://doi.org/10.5539/jms.v8n1p149

\begin{abstract}
This study mainly aims to investigate the impact of viral marketing dimensions, namely, promotion, brand awareness, trust and brand association on customer satisfaction in fast food restaurants in Jordan. The researcher used a questionnaire survey to elicit data from the participants. A total of 159 questionnaires were distributed over several fast food restaurants in Jordan, particularly in Zarqa city. Analyses were carried out in Statistical Package for Social Sciences, where reliability analysis, descriptive statistics and regression analyses were performed. The results illustrated that brand awareness, trust and brand association have direct positive impact on customer satisfaction in fast food restaurants in Jordan, whereas, promotion has no direct positive impact.
\end{abstract}

Keywords: viral marketing, customer satisfaction, fast food restaurants, Jordan

\section{Introduction}

In a developing e-commerce economy such as Malaysia, word-of-mouth (WOM) is considered more influential on consumer behaviour than other forms of marketing communications such as advertising and publicity. WOM is proven to influence awareness, expectations, perceptions, attitudes, behavioural intentions and behaviour (Ha, 2004). Viral marketing is becoming a key marketing strategy employed by many firms to achieve their goals. Viral marketing uses human instincts to communicate, share knowledge and socialise. The use of Internet presently is wide spread, and people of various ages tend to spend increased time online using friends-based social media, sometimes even more than watching TV, became advantageous to viral marketing; this marketing strategy can penetrate any individual's social network as easily as one mouse click that diffuses information to friends in the same social network. In addition, if the ad is sufficiently attractive, well designed and noticeable, then friends will distribute it in other social networks, thereby spreading it online like a viral contagion converting WOM to word of mouse.

Fast food restaurant firms know that the world is changing in their favour as the modern family tends to depend less on home-cooked meals and more on eating out, which increases the necessity of fast food. Fast food firms need to drive customers to their restaurants by building awareness, trust, and satisfaction toward their fast food brand.

Additionally, fast food firms in Jordan are challenged to satisfy a large number of customers. As service providers in the fast food industry increased, customers were provided unlimited options. As a result, they became demanding and disloyal moving from one fast food firm to another seeking for better services (Dzama, 2013). Service encounter(s) seems to be relegated to one area, which firms can use to attract and retain customers from their rivals. However, the fast food firms in the industry are not devoting sufficient efforts to improve customer satisfaction through effective service encounter, leading to customer dissatisfaction. Hence, the future of some players in the industry is threatened. Fast food firms are considering viral marketing to employ current online social networks in order to increase their direct and indirect influences over customers. In this research, the effects of viral marketing in the Internet on fast food restaurants customers through the dimension of promotion, awareness, trust and association are investigated. We will review various literatures on viral marketing and fast food customers' satisfaction. Additionally, we will consider subjects related to viral marketing from some popular fast food brands' websites to identify factors that may impact customer satisfaction. 


\section{Literature Review}

Viral marketing is a marketing technique that stimulates people to spread a product or a brand name advertisement with a marketing message to others in their social network. The passing on of the message creates an exponential growth of the advertisement visibility of "the marketed message" through targeted people or potential customers. Marketers can use different kinds of communication media to start seeding their initial message such as TV, magazines, newspaper and sometimes post mail. However, as the Internet makes its way through people's personal computers, laptops, tablets and even mobile phones which are accessible at any time, the Internet became the most favoured by marketers to efficiently deliver viral marketing messages at lower costs than TV or other forms of media.

The Internet provides numerous options to start seeding a viral marketing message including emails, blogs, online forums, YouTube, Flicker and other Web2 social media networks such as Facebook, Twitter and Google. Recently, marketers concentrated their efforts on social media networks because of their flexibility and dynamic means of holding various media from videos to music, as well as sound and text messages and the ability of these networks to reach customers directly. These networks have the unique feature of providing a direct statistical measure on how many times a certain message has been viewed, thereby giving marketers an option to monitor their efforts and researchers a key instrument to study viral marketing effects on customers. This feature justifies why we chose viral marketing conducted through social media networks in our study.

As illustrated in the previous paragraph, we will examine the viral marketing activities of some well-known fast food restaurant brands such as McDonald's and Burger King through the most utilised Internet social media websites and the websites of the aforementioned brands. We will determine the effects of "viral marketing" on fast food customers' satisfaction.

In a study by Dr. Rudaina Othman Yusef (2009) to measure viral marketing impact on purchasing decision with a sample of Internet users who are students of marketing at Zarqa Private University and Zaytuna University in Jordan. The results found a significant impact of viral marketing on customer decisions. A research by Shahzad et al. (2012) on the fast food industry in the Peshawar Pakistan region used a sample from restaurants such as KFC and Pizza Hut. The study indicated a significant positive relationship among promotion, service quality, customer expectations, brand, physical environment, price and taste of the product to customer satisfaction.

Fast food restaurant firms are engaging heavily in social media networks. Table 1 shows recent statistics on the number of fans of four of well-known fast food brands in their main pages or channels. In this study, we chose the following four famous social networks:

a. Facebook: Facebook is a popular free social networking website that allows registered users to create profiles, upload photos and videos and send messages and keep in touch with friends, family and colleagues. Available in various languages, each profile contains a wall serving as a virtual bulletin board that holds videos photos and text messages. Facebook has approximately 1,350 million users worldwide, and Table 1 shows the number of fans that hit like for fast food brand advertisements.

b. Twitter: Twitter is a free social networking microblogging service that allows registered members to broadcast short posts, short videos and photos. The platform is mainly for short blogging called "tweets," wherein registered members can follow freely the tweets of anybody they like and all the conversations related to each tweet. Twitter has approximately 284 million users worldwide, and Table 1 shows the number of followers for each brand.

c. Google+: Google+ or Google Plus is a social networking and identity service owned and operated by Google Inc. Google described Google+ as a "social layer" that enhances many of its online properties, enabling users to form social circles to interact with each circle individually giving it a powerful advantage over Facebook To date, Google+ has approximately 540 million active users, and Table 1 presents the number of followers for our fast food brands sample.

d. YouTube: YouTube allows people to discover, watch and share videos. YouTube also provides a forum for people to connect and inform and acts as a distribution platform for videos. Individuals and firms can create their own channels in the platform where they can upload their videos, and any YouTube user, whether subscribed to the channel or not, can see and download the said videos. Table 1 indicates the number of views of uploaded videos for each fast food brand.

The positive thing about online social networks is their availability to anyone with Internet access. Additionally, these networks provide a free statistical measure of each page wall or channel activity, giving marketers and researchers the ability to determine ads or video popularity among Internet users. 
Table 1. Viral marketing effort by the fast food brands

\begin{tabular}{llllll}
\hline Rank & Brand & Facebook fans & Twitter followers & Google+ views & YouTube views \\
\hline 1 & McDonalds & $54,801,660$ & $2.65 \mathrm{M}$ & $2,839,359$ & $20,178,606$ \\
2 & KFC & $36,160,982$ & $710 \mathrm{~K}$ & 105,739 & $5,996,033$ \\
3 & Burger & $7,503,751$ & $982 \mathrm{~K}$ & $6,277,539$ & $13,452,048$ \\
& King & & & \\
4 & $\begin{array}{l}\text { Popeye's } \\
\text { Chicken }\end{array}$ & 496,310 & $37,199 \mathrm{~K}$ & 13,125 & 72,101 \\
\hline
\end{tabular}

Table 1 illustrates some of the viral marketing efforts by fast food brands. The numbers are taken from their social media pages targeting US English speaking customers. Plenty of other pages from the same brand name targeting different regions and languages worldwide, McDonald's for example, has more than 30 million video viewers in their Canadian YouTube channel alone. In this study, we are using one region noting that marketers are using the same viral ideas with varying themes for different regions and languages. We observed that the Arabic language is not well represented in the efforts of fast food brands toward viral marketing. Except for promotional advertisements, neither videos nor direct communication are aimed at Arabic speaking customers to build trust in brand and quality of materials used in their products. This lack of representation may pose a concern later for fast food brands as Arabic content on the Internet is growing. Additionally, Arabs will soon become concerned about the kind and quality of food offered by fast food restaurants.

\section{Dimensions of Viral Marketing}

\subsection{Promotion}

Promotion is the communication of information between a seller and potential buyer or others in the channel to influence attitudes and behaviour. The marketing manager's main promotion responsibility is to inform target customers that the right product is available at the right place at the right price (McCarthy \& Pereault, 2002). At a quick glance of what kind of viral materials fast food brands have in their social networks, one will find that the first new promotions come with numerous beautiful pictures and short videos of seemingly delicious meal surrounded by happy faces. The promotion also shows the meal with an affordable price tag. Some promotions add value by offering customers something extra such as a free sandwich with each meal ordered or a large French fries at the price of a regular one. Another type of promotion we noticed that most fast food restaurants do to satisfy customers is providing a happy meal designed for kids because marketers know that customers will be satisfied if their kids are happy and satisfied. Other viral marketing messages show happy children with a meal in a restaurant and happy with a toy at home. From our perspective as illustrated from the paragraph above, promotion is an important dimension of viral marketing, and it can positively impact fast food customer satisfaction. Hence, promotion is our first independent variable as a dimension for viral marketing effect on fast food customers' satisfaction.

\subsection{Brand Awareness}

According to Keller (1993) "Brand awareness is the combination of brand recognition and brand recalling. Brand recognition means if a customer can have heard or seen a brand and then see or hear it again, the customer will remember the brand and distinct it from competing brands." One of the best examples of viral marketing campaigns for fast food restaurants we found in our review is Burger King's "Subservient Chicken" campaign launched in April 2004. The original video of the said viral marketing campaign which is available on YouTube presented a simple yet creative idea. In the video, a man wearing a chicken suit is in a living room and will do anything users tell him to do. An interactive website especially created for this campaign allows users to enter a command of anything they want the chicken to perform. The website will then ask the user to tell a friend by sending the link by email which spread virally between people.

The campaign was specially designed for this product and is a part of a successful massive marketing campaign mix for the campaign designer and Burger King. According to Andrew Schneller and John Marshall (2007) in their case "Social Media and the Burger King Brand," the sales of TenderCrisp chicken sandwiches increased by an average of $9 \%$ per week after the campaign.

This finding represents the success of the campaign. Brand awareness is defined as the "consumers" ability to identify the brand under different conditions as reflected by their brand recognition or recall performance (Kotler et al., 2012). We propose that the Subservient Chicken campaign rebuilt and improved the Burger King brand awareness. This awareness drove customers to Burger King restaurants, and if they found what they expect from previously positioned brand recognition in their minds, then they will be satisfied. Thus, brand awareness is the 
second dimension of viral marketing effect on fast food customer's satisfaction.

\subsection{Brand Trust}

Trust for fast food brands is a serious issue; they are already criticised by the media for targeting children and customers with unhealthy food. The food that fast food restaurants serve is filled with extra calories (Harris et al., 2010). According to Harris et al. (2010) in their research "Evaluating Fast Food Nutrition and Marketing to youth", people in the United States are shifting toward consuming more food outside their homes, and most of that consumption is from fast food restaurants due to heavy advertisement from fast food firms. The Internet is full of information about the relation of obesity to fast food brands, but this is not the full story. A new kind of small videos and pictures are shared widely in online social networks with a large number of viewers worldwide, spreading virally.

Americans used to call fast food products as junk food, but videos as illustrated above adds the terms "disgusting" and "unhealthy." Imagine what these videos and pictures from unknown origins spreading in social networks could do to a customer's trust on fast food restaurant brands. McDonald's and other fast food brands must defend themselves against negative viral marketing information. Excellent marketers should find a way to turn negative viral marketing into a positive one. McDonald's was the first to act by launching a huge viral marketing campaign called "Our Food, Your Questions." Perhaps because McDonald's is the largest fast food firm spending on advertisement and one of their products is directly mentioned in the "Red Slime videos," the company based their new campaign on viral marketing techniques. The campaign was designed to answer direct questions from customers about the ingredients of their meals especially relating to beef and chicken. To capture questions, the campaign uses Twitter and Facebook, and they utilised well-designed videos to provide answers, allowing the videos to be shared by customers themselves in their own social media accounts.

According to MacCarthy \& Perrealt, (2002), "customers can trust information that is the same information used by someone inside the company." McDonald's marketing communication channels through social media are reaching a wide range of customers, which reflects the efficiency of social media to hold viral marketing messages. MacDonald's is trying to say that "bad ingredients may be used in fast food restaurants but not by McDonald's probably because of people's curiosity towards what they eat". We propose that through McDonald's "Our Food, Your Question" campaign, the brand can regain their customers' trust which led to customers satisfaction. From our perspective, trust is one dimension of viral marketing that impact on fast food customers' satisfaction.

\subsection{Brand Association}

Brand associations are the informational nodes linked to the brand node in memory and contain the meaning of the brand for consumers. Thus, brand association is what the consumer likes about the brand. For brands that bring meaning to consumer, According to Keller, (1993), it is important that consumers have good, strong and special associations to the brand when building brand equity. Keller $(1993,1998)$ classified brand associations into three major categories: attributes, benefits and attitudes. Attributes are descriptive features that characterise a brand such as what a consumer thinks the brand is or what it has and what is involved with its purchase or consumption. Benefits are the personal value consumers attach to the brand attributes, that is, what consumers think the brand can do for them. Brand attitudes are consumers' overall evaluations of a brand.

Viral marketing can influence the feeling of customers toward the value and personality of the brand. Viral marketing also influences descriptive features and characteristics of the products related to the brand which consist the brand association concept. In this study, we consider brand association as a dimension of viral marketing effects on fast food restaurants customers' satisfaction.

The basic objective of this study is to posit the relationships among customer satisfaction. Figure 1 depicts the conceptual framework of relationships among dimensions of viral marketing and customer satisfaction. 


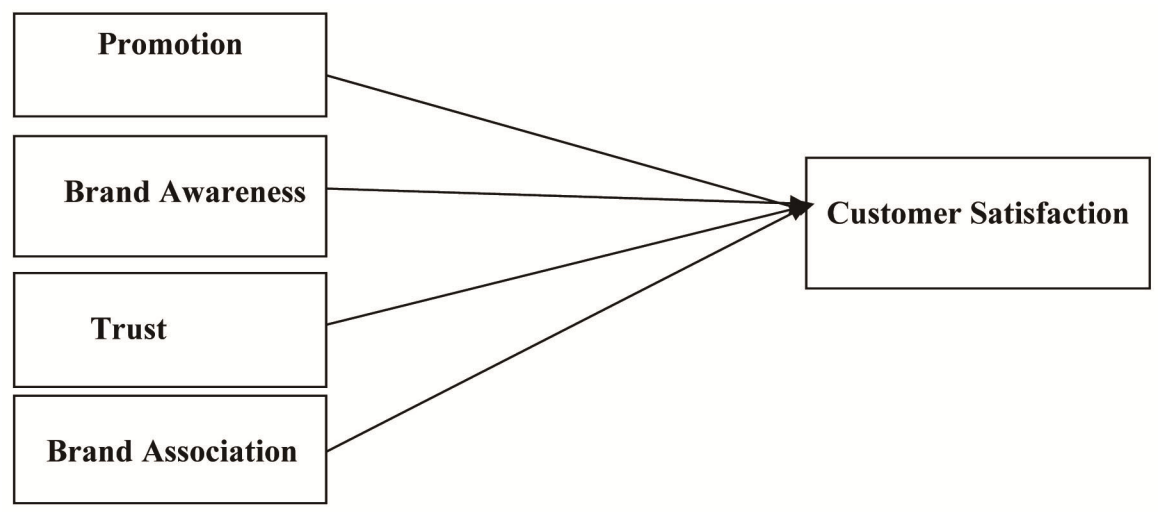

Figure 1. Model of study

\section{Hypothesis of the Study}

There is a relationship between dimensions of viral marketing on customer's satisfaction in fast food restaurants in Jordan. This section includes the hypothesis information of this study as discussed below:

H1: Promotion is positively related to customer satisfaction.

H2: Brand awareness is positively related to customer satisfaction.

H3: Trust is positively related to customer satisfaction.

H4: Brand association is positively related to customer satisfaction.

\section{Methodology}

This study utilises a quantitative research design to investigate the predictors of customer satisfaction in fast food restaurants in Jordan. The population of this study consists of customers in fast food restaurants in the country. Customers were selected for the following reasons (Keller, 1993, 1998; Shahzad et al., 2012): First, it has been used in past studies. Second, customers can use correct information regarding the model such as dimensions of viral marketing and customer satisfaction. Third, customers in destinations in Jordan have fresh memories according to their experiences and reasons of customer satisfaction.

A systematic random sample of 150 respondents was selected from five restaurants in the capital of Jordan, Amman. The questionnaire is divided into four parts: part (1) includes demographic variables (8 items); part (2) consists of dimensions of viral marketing which are promotion (9 items) adapted from Al Muala \& Al Qurneh (2012), trust (5 items) adapted from Al Muala (2016) and for brand awareness (4 items) and brand association (6 items) adapted from Zhou et al. (2008) and customer satisfaction (10 items) adapted from Al Muala \& Al Qurneh (2012). In addition, this study used SPSS 20.0 to provide more goodness of fit indices for the full structural model, thereby yielding superior empirical results (Hair et al., 2006). All variables were measured using a five-point Likert scale where (1) is strongly disagree, (2) is disagree, (3) is undecided, (4) is agree and (5) is strongly agree.

\section{Results}

\subsection{Profile of the Respondents}

The respondents' ages ranged from 20 to over 50 years old. Male respondents $(35.2 \%)$ are greater than females $(64.8 \%)$. The majority of participants was single (84.3\%). Finally, most respondents $(79.2 \%)$ have an income of less than $\$ 1000$.

\subsection{Reliability and Normality}

This study consists of four constructs, namely, promotion, brand awareness, trust and brand association, as well as a construct variable which is customer satisfaction. As shown in Table 2, each construct indicates an acceptable Cronbach alpha value of above 0.60 (Nunnally, 1970). Reliability values for all constructs ranged from .69 to .90 , which indicates that all constructs have acceptable internal consistency. 
Table 2. Descriptive statistics of constructs

\begin{tabular}{lllll}
\hline Construct & Original Items & Total Mean & Standard Deviation & Reliability \\
\hline Promotion & 6 & 4.31 & 1.17 & .78 \\
Brand Awareness & 5 & 4.23 & 1.12 & .69 \\
Trust & 4 & 4.40 & 1.21 & .77 \\
Brand Association & 9 & 4.52 & 1.02 & .82 \\
Customer Satisfaction & 10 & 4.37 & 1.21 & .90 \\
TOTAL & 34 & & & \\
\hline
\end{tabular}

\subsection{Hypotheses Results}

This study tested four hypotheses. As rule of thumb, the hypothesis is accepted if its t-values is more than 1.96 and P values $>0.05$ (Hair et al., 2006). Analysis results for testing the hypothesis are shown in Table 3.

Table 3. Regression analysis

\begin{tabular}{llllll}
\hline Hypothesis & \multirow{2}{*}{ From } & To & t-value & $\begin{array}{c}\text {-value } \\
\text { (Sig) }\end{array}$ & Result \\
\hline H1 & Promotion & Customer Satisfaction & 1.75 & .08 & No \\
H2 & Brand Awareness & Customer Satisfaction & 3.48 & .001 & Yes \\
H3 & Trust & Customer Satisfaction & 3.09 & .002 & Yes \\
H4 & Brand Association & Customer Satisfaction & 3.38 & .001 & Yes \\
\hline
\end{tabular}

The findings support three hypotheses of the study (H2, H3 and H4) whereas one hypothesis, which is $\mathrm{H} 1$, was rejected. The data indicate that most findings are significantly and positively related to customer satisfaction.

\section{Conclusion}

This study examines the impact of promotion, brand awareness, trust and brand association on customer satisfaction. Thus, the four hypotheses of promotion, brand awareness, trust and brand association were tested directly.

The results show that brand awareness has a positive impact on customer satisfaction, which confirms the importance of brand awareness. Moreover, customer's trust has a positive effect on customer satisfaction, which means that customers consider the importance of the services in fast food restaurants in Jordan. Furthermore, brand association has a positive impact on customer satisfaction. Additionally, promotion has an insignificant and positive impact on customer satisfaction. This finding means that the use of promotion about services provided by restaurants is unimportant to customers of fast food restaurants in Jordan. Based on these results; the researcher recommends that fast food restaurants in Jordan should focus more on promotion, brand awareness, trust and brand association to improve service quality and satisfy their customers.

\section{References}

Al Muala, A. M., \& Al Qurneh, M. (2012). Assessing the Relationship between Marketing Mix and Loyalty through Tourists Satisfaction in Jordan Curative Tourism. American Academic \& Scholarly Research Journal, 4(2).

Al Muala, M. (2016). Factors Affecting University Students' Intention to use Facebook: a case study of Zarqa University. EPRA International Journal of Economic and Business Review, 4(11).

Dzama, T. (2013). SERVICE ENCOUNTERS IN THE FAST FOOD INDUSTRY-CASE OF MIDLANDS PROVINCE. International Journal of Marketing, Financial Services \& Management, 2(5).

Harris, J. L., Schwartz, M. B., \& Brownell, K. D. (2010). Fast Food FACTS: Evaluating Fast Food Nutrition and Marketing to Youth. Rudd Center for Food Policy and Obesity.

Hossein, N., Yen, L. K., \& Omid, A. (2011). Factors influencing customer satisfaction towards fast food restaurants. International Conference on Sociality and Economics Development IPEDR (vol. 10). IACSIT Press, Singapore.

Ida, N., \& Magnus, S. (2009). The Viral makes you aware. Kristianstad University College International Business and Economics Program.

Jason, Y. C. H., \& Melanie, D. (2010). Viral marketing: Motivations to forward online content. Journal of 
Business Research, 63, 1000-1006. https://doi.org/10.1016/j.jbusres.2008.08.010

Johanna, R., \& Harris, J. L. (2011). Food Marketing and Social Media: Findings from Fast Food FACTS and Sugary Drink FACTS. Rudd Center for Food Policy \& Obesity at Yale University.

Judith, C., \& Dina, M. (2004). The Effect of Word Mouth on Sales. On Line Book Reviews.

Kevin Lane Keller Source. (2013). Conceptualizing, Measuring, and Managing Customer-Based Brand Equity, American Marketing Association. Retrieved from http://www.jstor.org/stable/1252054

Kotler, P., Keller, K. L., Hassan, S., Baalabki, I., \& Shamma, H. (2012). Marketing Management. Arab World Edition.

Saleh, A., \& Amir, G. (2011). Impact of perceived value on word of mouth endorsement and customer satisfaction: mediating role of repurchase intentions. International journal of Economic and Management Sciences, 1(5), 46-54.

Shahzad, K., Syed, M. H., \& Fahad, Y. (2012). Determinants of customer satisfactions food industry. International Journal of Management and Strategy, 3. Retrieved from http://www.facultyjournal.com

Tuck School of Business at Dartmouth-Glassmeyer/McNamee Center for Digital Strategies. (2007). Social Media and the Burger King Brand Case \#6-0025.

William, D., Perreault, Jr., \& McCarthy, E. J. (2002). Basic Marketing A Global-Managerial Approach (14th ed.).

Woerndl, M., Papagiannidis, S., Bourlakis, M., \& Li, F. (2008). Internet-induced marketing techniques: Critical factors in viral marketing campaigns. Int. Journal of Business Science and Applied Management, 3.

\section{Copyrights}

Copyright for this article is retained by the author(s), with first publication rights granted to the journal.

This is an open-access article distributed under the terms and conditions of the Creative Commons Attribution license (http://creativecommons.org/licenses/by/4.0/). 